\title{
How Economic Rights for SMEs Protected? Analysis of National and International Property Rights Law
}

\author{
Waspiah $^{1^{*}}$, Rodiyah ${ }^{2}$, Dian Latifiani ${ }^{3}$, Ridwan Arifin ${ }^{4}$ \\ 1,2,3,4 Faculty of Law, Universitas Negeri Semarang, Indonesia \\ Corresponding Author: Waspiah, email: waspiahnajib@mail.unnes.ac.id
}

\begin{abstract}
Small and Medium Enterprises (SMEs) in Indonesia are growing rapidly and continuing to grow. These developments had a significant impact on economic growth for various sectors in Indonesia. However, the dynamics of the development of SMEs are still overshadowed by the unclear protection of rights relating to intellectual property, including economic rights for SMEs. In fact, this right becomes an important part that is regulated both in national and international legal rules. The purpose of this study is to determine and compare the implementation of the protection of economic rights for SMEs in Central Java Province, Indonesia. This research method uses interview techniques and direct observation in several SMEs in Central Java. This study found that the protection of economic rights for SMEs had not been maximally carried out, even the number of SMEs did not yet obtain guaranteed recognition of the brand rights and copyrights of their products. This study concludes that in applying protection to economic rights for SMEs, collaboration between sectors and ministries is needed, not only the Ministry of Law and Human Rights, but also Industry, Trade and Economy.
\end{abstract}

Keywords: Economic Rights; Small and Medium Enterprises; Intellectual Property Rights; International Law; National Law

\section{How to cite:}

Waspiah, W., Rodiyah, R., Latifiani, D., \& Arifin, R. (2020). How Economic Rights for SMEs Protected? Analysis of National and International Property Rights Law. Indonesian Journal of Advocacy and Legal Services, 2(1), 71-88. https://doi.org/10.15294/ijals.v2i1.35285

\section{A. Introduction}

National economic development based on Article 33 paragraph (1) of the 1945 Constitution of the Republic of Indonesia (1945 Constitution) aims to improve 
the welfare of the people as a whole, not the welfare of individuals or groups and certain groups. Therefore, the national economy must be arranged as a joint effort based on the principle of kinship to achieve prosperity and prosperity. To realize the people's welfare, it is done through various efforts, one of which is to increase the competitiveness of Micro, Small and Medium Enterprises (hereinafter referred as SMEs) in Indonesia at this time.

The role of SMEs has a strategic value in strengthening the national economy (people's economy) so the government should give proper attention (strategy and policy) for empowerment (priority and alignment), which is seen as a group of business units that should be integrated in the national business world later can increase the standard of living and competitiveness. SMEs as the forerunners of the process of entrepreneurship need to be given closer attention from various aspects.

Since the change of the new order government from the old order, until the reform era, economic development has become the Indonesian Government's top priority. Underdevelopment and the severe poverty left by the old order became the strong foundation of the desire of the new order government to develop the Indonesian economy as a means to progress and prosperity of the people and it was also realized in the reform era government. Furthermore, the industrialization process as carried out by developed countries and is believed to be able to bring breakthroughs that are quickly implemented, with the hope that Indonesia's traditional agricultural community will gradually become a modern industrial society. ${ }^{1}$

Data from 2011 showed that the foreign exchange of SMEs has proven to be able to make a significant contribution to the formation of national gross domestic product (GDP) and exports. SMEs contribute 55.6 percent of current price GDP with an investment value of Rp 640.4 trillion or 52.9 percent of the total investment. Not only that, SMEs also earned foreign exchange of Rp 183.8 trillion or $20.2 \%$ of the total economic sector in Indonesia. In 2010 SMEs in Indonesia were more than the number of SME actors. That is as much as 51.3 million business units or 99.91 percent of the total number of business operators in Indonesia. The total workforce reaches 90.9 million workers, equivalent to 97.1 percent of all Indonesian workers. Even the Data of the Central Statistics Agency released the situation after the economic crisis the number of SMEs did not decrease, instead it increased its growth the most, even able to absorb 85 million to 107 million workers until 2012. In that year the number of employers in Indonesia was 56,539,560 units. From this

Kusumanigtuti, S.S., Peranan Hukum dalam Penyelesaian Krisis Perbankan di Indonesia, Jakarta, Rajawali Press, 2019, pp. 36-38. 
number, SMEs were 56,534,592 units or 99.99\%. The remaining around $0.01 \%$ or 4,968 units are large scale businesses. This phenomenon explains that SMEs are productive businesses to be developed to support macro and micro economic development in Indonesia and affect other sectors that can develop. One of the sectors that are affected by SME growth is the banking service sector that is audible, because almost 30\% of SME businesses use operational capital from banks.

However, within the SMEs itself still has many problems. The real performance faced by most businesses, especially SMEs in Indonesia that is most prominent is the low level of productivity, low value added, and low quality of products. It must be acknowledged that SMEs provide employment for most workers in Indonesia, but the contribution to national output is categorized as low. This is because SMEs, especially micro and small businesses (which absorb a lot of labor), have very low productivity. If wages are used as productivity, average wages in micro and small businesses are generally below the minimum wage. This condition reflects the productivity of the micro and small sectors is very low when compared to larger businesses. $^{2}$

Meanwhile, Yoserwan ${ }^{3}$ revealed that policies that were more focused on achieving economic growth had resulted in the government prioritizing the development of large companies with the aim of generating foreign exchange. The policy was carried out with the assumption that the growth of its land would naturally give rise to equal welfare for the people, in accordance with the trickledown effect theory. So, this has caused various problems in SMEs, especially in Indonesia. This theory-trickledown effect-recognized as an empowerment intervention whose first objective does not have to be marginal or poor communities. The emphasis is on intervention in people who have great potential, especially a matter of speed to develop. This approach emphasizes the emergence of growth because with the emergence of growth there will be a trickledown effect that will bring improvements to the welfare of the community, including the poor. If there are 100 people who will be empowered, just take one or two people first. With concentration in few people, attention can be fully concentrated. When one or two of these people

2 Arto, A., \& Hutomo, B.S. "Enam Pilar Insektisida" Kebijakan Pengembangan dan Penguatan UMKM Berbasis Kerjasama Kemitraan dengan Pola CSR Sebagai Strategi Peningkatan Peran Pemerintah dan Perusahaan untuk Menjaga Eksistensi UMKM dalam MEA 2015', Economics Development Analysis Journal, Vol. 2 No. 2, 2013, pp. 98-109

3 Yoserwan, Hukum Ekonomi Indonesia dalam Era Reformasi dan Globalisasi, Padang, Andalas University Press., 2006, pp. 57-59. 
have succeeded, he can be asked to participate in fostering the empowerment of the surrounding community. With high achievement motivation, they finally succeeded, and it is this success that drives the community's economy. This success will bring the consequences of labor demand and raw materials to the surrounding community, and even bring up small shops or food stalls that provide the needs of employees. In many cases, there are those who have worked for the first person to be independent or go out alone to emulate so that similar businesses emerge in one area. This is called trickledown effect. Without being moved, automatic growth will appear. ${ }^{4}$

The problems of SMEs involve a number of issues, such as structural imbalances in the allocation and control of resources, uncertainty in the state's partisanship in developing the people's economy in policies and developing industrialization strategies, oligopolistic market structures, relatively limited performance in classical terms (classical human resources or human resources, capital and access to financial institutions, technology, management, marketing and information), the occurrence of policy distortions and inconsistencies concerning development efforts. ${ }^{5}$ (Hubeis, 2015; Arliman 2017). Another issue relates to economic contributions in the context of economic rights in the development of SMEs in Indonesia such as trademarks and branding. Previous researches highlighted the problems of economics contribution especially concerning to the legal protection. ${ }^{6}$

In responding to the economic contribution of the copyright-based industry, there are some basic concepts that must be stated to build the same perception. First, this research takes the definition of copyright as an individual property. Although there may be what is called communal

4 Jaya, P.H.I. 'Trickle Down Effect: Strategi Alternatif dalam Pengembangan Masyarakat', WELFARE, Jurnal Ilmu Kesejahteraan Sosial, Vol. 1 No. 1, 2012, pp. 6986; Wilantara, R. F., \& Indrawan, R. Strategi dan Kebijakan Pengembangan UMKM: Upaya Meningkatkan Daya Saing UMKM Nasional di Era MEA, Bandung, Refika Aditama, 2016, pp. 58-60. See also, Darwin, D. 'UMKM dalam Perspektif Pembiayaan Inklusif di Indonesia (MSMEs on Inclusive Financing Perspective on Indonesia)', Jurnal Ekonomi dan Pembangunan, Vol. 26 No. 1, 2018, pp. 59-76.

$5 \quad$ Hubeis, M., Prospek Usaha Kecil dalam Wadah Inkubator Bisnis. Bogor, Ghalia Indonesia, 2015, pp. 77-78; Arliman, L. 'Perlindungan Hukum UMKM dari Eksploitasi Ekonomi dalam Rangka Peningkatan Kesejahteraan Masyarakat (UMKM Legal Protection from Economic Exploitation to Improve Social Welfare)'. Jurnal Rechtsvinding, Vol. 6 No. 3, 2017, pp. 387-402.

6 Cakrawibawa, R.A., \& Roisah, K. 'The Consumer Protection Issues Toward the Trademark Circulation of The Counterfeit Health Products', Law Reform, Vol. 15 No. 2, 2019, pp. 1-11; Hayuningrum, Y.W., \& Roisah, K. 'Perlindungan Hak Ekonomi Terhadap Penggunaan Merek dalam Perjanjian Waralaba', Law Reform, Vol. 11 No. 2, 2015, pp. 255-263; Roisah, K. 'Kebijakan Hukum "Tranferability" Terhadap Perlindungan Hak Kekayaan Intelektual di Indonesia', Law Reform, Vol. 11 No. 2, 2015, pp. 241-54. 
copyright, the basis for studying the economic contribution of copyright is recognition of copyright as private property. Property rights are defined as "the ability of individuals to own, buy, sell and use their property in a market economy" (WIPO, 2002). Being a property right, the economic value of copyright can be measured and calculated with a certain methodology.

The methodology developed to calculate the economic contribution of copyright is based on an understanding of the difference between a work protected by copyright and the 'means of delivery' or means of delivery where the work appears on the market and is available for consumption. WIPO (2002) states that the main difference between protected work and shipping methods is that the first has the characteristics of public goods, while the way to delivery is usually private goods. For example, songs are protected by copyright, but music CDs are shipping tools. Copyrights itself only refers to aspects of intellectual property, and not the means of delivery. However, the shipping method is an intermediary of the copyright for consumption by the market. The functional relationship between production and trade with shipping equipment is interdependence. Therefore, the methodology developed to calculate the economic contribution of copyright includes several proportions of activities in the delivery of copyright products. ${ }^{7}$

Then various issues related to economic contributions and economic rights in the acquisition of copyright for SMEs in Indonesia are the focus of this paper.

\section{B. Method}

The paradigm used in research is Constructivism (Legal Constructivism) in the context and substance of the substance of policy formation. ${ }^{8}$ The constructivist paradigm is as a critique of positivistic social science. Constructivism can be traced from Weber's thought which characterizes that human behavior is fundamentally different from natural behavior. Humans act as agents in producing social reality. The way construction is carried out on how to understand or give meaning to their own behavior. Legal Constructivism simply incorporated the epistemology of welfare economics for

7 Dewi, I.J. 'A Study on the Economic Contribution of Copyright and Related Right Industries in Indonesia'. Procedia-Social and Behavioral Sciences Vol. 115, 2014, pp. 207-220

8 Agus Salim, Teori dan Paradigma Penelitian Sosial (Pemikiran Norman K. Denzin dan Egon Guba, dan penerapannya), Yogyakarta, PT. Tiara Wacana, 2001, p. 33; Norman Denzin and YS Lincoln, Introduction: The Discipline and Practice of Qualitative Research. In N Denzin and YS Lincoln, eds, Handbook of Qualitative Research, Second Edition, London, Sage, 2000), p. 125 
the purpose of factual analysis. But it is an activist and "progressive" political strategy that Ackerman believes the New Deal revolution compels legal culture to pursue. ${ }^{9}$

This research is an empirical legal research. This means that the enactment of the law must be in accordance with higher rules, or the formation of the methods that have been determined at the same time to find out how the law is implemented in the law enforcement process. This research will examine the right to economy in copyright for SMEs in Indonesia in the context of national and international legal rules. Research data obtained by conducting interviews, observation, interpretation of documents and materials and personal experience. In accordance with the constructivism paradigm and the hermeneutic approach, the researcher takes the position as a facilitator in conducting observations using the participatory principle. Indepth interviews were conducted with open-ended questions but did not rule out the possibility of being conducted closed especially with informants who had a lot of information. ${ }^{10}$

\section{Result and Discussion}

\section{Basic Concept of Economic Rights Protection for SMEs}

Intellectual Property must be seen as a power tool for economic growth, not an unclear legal concept. Intellectual Property Rights protection plays an important role in driving technological change and facilitating economic growth. The value of intellectual property is often not adequately valued and its potential to provide opportunities for potential future benefits is broad and is often underestimated by SMEs. However, when intellectual property is legally protected and there is demand for products and or services where intellectual property is protected in the trade and market sectors, intellectual property can become a valuable business asset ${ }^{11}$, and copyright is included in the scope of intellectual property studies.

The birth and development of copyright in the realm of material law has a long chronological journey and have experienced dark periods in its history. In general, the history of the birth of copyright is considered to begin in England in the early 17th century and in France at the end of the 17th

Alexander, G.S. 'Interpreting Legal Constructivism', Cornell Law Review, Vol. 7 No. 1, 1985, pp.149-254.

10 Ridwan Arifin, Waspiah, \& Dian Latifiani, Penulisan Karya Ilmiah untuk Mahasiswa Hukum, Semarang, BPFH UNNES, 2018, pp. 35-37.

11 Sukarmijana, S.S. \& Sapong, O.D.V. 'The Importance of Intellectual Property for SMEs: Challenges and Moving Forward'. UMK Procedia 1, 2014, pp. 74-81 
century. The reason for the history of the birth of copyright began in England and France is because Britain and France are considered to represent the two legal system regimes in force in the world today. The two different legal systems have also given rise to the concepts of economic right and moral right in copyright. From the history of the birth of the copyright of the two countries, we can understand why common law countries generally prioritize the economic rights (creation rights) of a work rather than the personal rights of the creator as practiced in civil law countries that have given birth to moral rights. ${ }^{12}$

The basic concept of economic rights begins with the history of copyright in the United Kingdom born on the foundation of the practical business of printing and publishing books that are very monopolistic and capitalistic that ignores the creator's personal rights to his creation, but along with its development experienced changes which initially only for the benefit of business for the British empire then turned out to be perfect with the recognition of the creator manifested in the form of economic royalties and also on the foundation of Jhon Locke's thought at the time. ${ }^{13}$

Meanwhile, the concept of moral rights developed initially in France, almost the same as in England, but in France the copyright is known as the droit d'auteur or copyright in France is different from the concept of copyright in England. The concept of droit d'Aauteur places a creation as de l'esprit or a work of mind which is the result of human intellectuals. Therefore, a work is inseparable from the personality of the creator and this right will be forever attached to the creator even though the work is transferred ownership to another party. Based on the concept of droit d'auteur which also inspired the birth of the concept of moral rights from an unknown creator in common law countries and also the ideas of George Hegel who at that time in France which recognized that human self-identity arising from his work or creation.

Furthermore, related to economic rights, it is also said that the value of a copyrighted work is determined by the beauty of the appearance, the uniqueness of the form, or scarcity, as well as the aesthetic and artistic nuances that can be enjoyed by the public. The reputation of previous works and the scarcity of their availability also affect the value of the work. Often a creator limits his creation in a limited number. Often the greatness of the previous creation becomes the prestige of quality equalizers. In addition, the means of promotion, including ways of sensation and criticism can be a factor in boosting the economic value of creation. These factors play a role in

12 Ginting, E.R. Hukum Hak Cipta Indonesia, Bandung, PT. Citra Aditya Bakti, 2012, pp. 78-79.

$13 \quad$ Ibid., pp. 86-87 
building people's interest and attention which in turn will form a strong and broad market segment. All of these factors basically complement the economic valuation of the creation, in addition to all the components that have been contributed by the creator, both in the form of time, energy and cost in creating his work. ${ }^{14}$

Economic rationality also further justifies copyright protection. In essence, protection must be given to allow all the costs and efforts of the creators to be repaid. Copyright protection is not solely directed at protecting the creativity of the creator, but on the economic interests associated with the creation.

Meanwhile, the provisions concerning economic rights are stipulated in the Copyright Act (Article 8 of Law Number 28 of 2014 concerning Copyright), where economic rights are the exclusive right of the creator or copyright holder to obtain economic benefits for the work. Utilization of the economic right to do: (1) Issuance of the work; (2 Doubling of creation in all its forms; (3) Translation of creation; (4) The adaptation, arrangement, or transformation of the work; (5) Distribution of works or copies; (6) Performing creations; (7) Announcement of the work; (8) Communication of creation; and (9) Rental of creation.

The content of economic rights is definitively affirmed in Articles 1 number 5 and 6 of the Copyright Act No. 19 of 2002, respectively concerning Announcement and Reproduction. ${ }^{15}$ In Article 1 number 5 of the Copyright Law Number 19 of 2002 which stated that Announcement is the reading, broadcasting, exhibition, sale, distribution, or distribution of a work using any instrument, including internet media, or doing in any way so that a work can be read, be heard or seen by others. Whereas in Article 1 Number 6 of the Copyright Law Number 19 of 2002, stated that multiplies is the addition of the amount of something created, both in whole or in very substantial part by using the same or unequal materials, including permanent or temporary transform. ${ }^{16}$

Furthermore, in the same context, the protection of economic rights for SMEs in Indonesia is regulated not only in the Copyright Act, but also the 1945 Constitution and the Law on SMEs. Article $28 \mathrm{H}$ of the 1945 Constitution of the Republic of Indonesia stated that: "Everyone has the right to get special facilities and treatment to obtain equal opportunities and benefits to achieve equality and justice." In the context of developing the

14 Soelistyo, H. Hak Cipta Tanpa Hak Moral, Jakarta, Rajawali Press, 2011, pp. 25-28.

Ibid., pp. 30-31

Waspiah, W. Teori dan Perkembangan Hukum Kekayaan Intelektual (Dinamika Nasional dan Internasional). Semarang, BPFH UNNES, 2019, pp. 55-57. 
business climate, various affirmative policies for SMEs have been implemented through various Legislation, including Law Number 20 of 2008 concerning Micro, Small and Medium Enterprises (SMEs Act), which was drafted with the intention of increasing the capacity and participation of Micro, Small and Medium Enterprises in the national economy. In the provisions of Article 7 of the SMEs Act it is emphasized that the Government and Regional Governments foster a Business Climate by stipulating laws and regulations that include aspects of: $a$. funding; $b$. facilities and infrastructure; $c$. business information; $d$. partnership; $e$. business licensing; $f$. business opportunity; g. trade promotion; and $h$. institutional support. In addition, the Government and Regional Governments are also instructed by the UMKM Law to facilitate business development in the fields of: $a$. production and processing; $b$. marketing; $c$. human Resources; and $d$. design and technology. ${ }^{17}$

\section{Implementation of Protection of Economic Rights for SMEs in Indonesia (National and International Context)}

In order to foster a business climate and facilitate business development, the Government and Regional Governments facilitate ownership of intellectual property rights for products and designs of Micro, Small and Medium Enterprises in domestic and export business activities and encourage Micro, Small and Medium Enterprises to obtain rights certificates for intellectual property.

As it is known that the Protection of Intellectual Property has an important meaning for the business world. Intellectual property is the key to competition and the development of a business. Understanding Intellectual Property Rights (IPR) is not only useful to protect business, but also ensures that a business does not violate the law due to IPR violations. SMEs as national economic actors have a very important role in economic development, this is because their business activities are able to expand the workforce and provide broad economic services to the community. Therefore, it is fitting for SMEs to have the same opportunity and even to be given special privileges, especially in the field of intellectual property.

Based on the provisions of Article 1 jo Article 6 of Law Number 20 of 2008 concerning Micro, Small and Medium Enterprises, it is stated that:

a) Micro businesses are productive businesses owned by individuals and / or individual business entities that meet the criteria of having net assets of

17 Sihombing, E.N.A.M. 'Kebijakan Afirmatif Bagi Usaha Mikro, Kecil dan Menengah di Bidang Kekayaan Intelektual (Affirmative Policy for Micro, Small and Medium Enterprises in the Field of Intellectual Property)', Rechtsvinding, Vol. 7 No. 3, 2018, pp. 427-444; Waspiah. Ibid., pp. 60-61. 
no more than $\mathrm{Rp} 50,000,000$ (fifty million rupiah) excluding land and buildings where the business is located; or have annual sales results of at most Rp.300,000,000.00 (three hundred million rupiah).

b) Small Business is a productive economic business that stands alone, which is carried out by individuals or business entities that are not subsidiaries or branch companies that are owned, controlled, or become a part either directly or indirectly of Medium Enterprises or Large Enterprises that meet criteria for having a net asset of more than Rp 50,000,000 (fifty

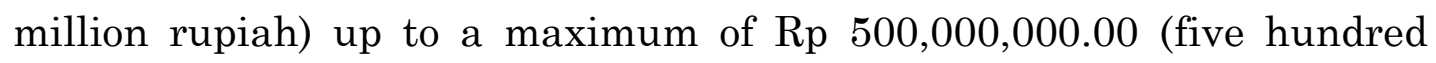
million rupiah) excluding land and buildings for business premises; or has annual sales results of more than Rp.300,000,000.00 (three hundred million rupiah) up to a maximum of Rp2,500,000,000.00 (two billion five hundred million rupiah).

c) Medium Business is a productive economic business that stands alone, which is carried out by individuals or business entities that are not subsidiaries or branch companies that are owned, controlled, or become a part either directly or indirectly with Small Business or Large Business with the criteria of owning net assets of more than Rp.500,000,000.00 (five hundred million rupiah) up to a maximum of Rp10,000,000,000.00 (ten billion rupiah) excluding land and buildings for business premises; or has annual sales results of more than $\mathrm{Rp} 2,500,000,000.00$ (two billion five hundred million rupiah) up to a maximum of Rp50,000,000,000.00 (fifty billion rupiah).

In addition to using monetary values as a criterion for determining the types of SMEs, a number of government agencies, such as the Central Statistics Agency (BPS), have also used the number of workers as a measure to differentiate business scales between micro, small, medium and large businesses. According to BPS, micro businesses (or in the general manufacturing industry sector called the home industry) are business units with a number of permanent workers of up to 4 people, small businesses of between 5 and 19 workers; and medium-sized businesses between 20 and 99 workers. ${ }^{18}$

Furthermore, it some researches emphasized that Small-medium sized Enterprises (SMEs) play a pivotal role in both developed and developing economies in terms of employment generation, output growth, export growth, poverty alleviation, economic empowerment and the wider distribution of

18 Taufik, A.I. 'Evaluasi Regulasi dalam Menciptakan Kemudahan Berusaha Bagi UMKM', Rechtsvinding Vol. 6 No. 3, 2017, pp. 375-392. 
wealth. ${ }^{19}$ However, it is also highlighted that for many SMEs their full potential is often not realized due to a number of factors relating to the scale of their businesses: lack of resources (finance, technology, skilled labor, market access, and market information); lack of economies of scale and scope; higher transaction costs relative to large enterprises; lack of networks that can contribute to a lack of information, knowledge and experience of domestic and international markets; increased market concentration with globalization; an inability to compete against larger firms in terms of R\&D expenditure and innovation (product, process and organization); they are subject to considerable 'churning' and instability; and they lack entrepreneurial zeal and know-how. ${ }^{20}$ In addition, many small businesses find that their geographical isolation puts them at a competitive advantage. Despite these substantial obstacles the East Asian region remains heavily dependent upon SMEs, particularly for employment generation, including Indonesia.

In accordance with the times, the regulation of the rights possessed by every human being, including the case with Intellectual Property Rights (IPR), is a necessity. ${ }^{21}$ Intellectual Property Rights (IPR) is a right that is born from the results of human thought if realized in the form of intellectual work. Wiradirja \& Munzil ${ }^{22}$ stated that IPR is a right that comes from the results of creative activities, the ability of human thought that has benefits and is useful in supporting human life, also has economic value. Considering that IPR is the result of creative activities, it is fitting for IPR to obtain legal protection. Robert M. Sherwood, as quoted by Wiradirja \& Munzil (2018), stated that various theories that underlie the need for legal protection for IPR, namely:

1) Reward Theory, which has a very deep meaning on intellectual work that has been produced by someone so that the inventor/creator or designer must be given an award as a counterpart to his creative efforts in finding / creating the intellectual work.

19 Harvie, C. (2010). 'SMEs and Regional Production Networks', on Thanh, V.T., Narjoko, D., Oum, S. (eds). (2010). 'Integrating Small and Medium Enterprises (SMEs) into the More Integrated East Asia', ERIA Research Project Report No. 8.

20 Ibid.

21 Djulaeka, D. Konsep Perlindungan Hak Kekayaan Intelektual (Perspektif Kajian Filosofis HaKI Kolektif Komunal), Malang, Setara Press, 2014, p. 22

22 Wiradirja, I.R., \& Munzil, F. Pengetahuan Tradisional dan Hak Kekayaan Intelektual (Perlindungan Pengetahuan Tradisional Berdasarkan Asas Keadilan Sui Generis Intellectual Property System). Bandung, Refika Aditama, 2018, pp. 36-39. 
2) Recovery Theory, states that the inventor / creator or designer who has spent time, money and energy in producing his intellectual work must recover what he has issued.

3) Incentive Theory, which links the development of creativity with providing incentives needs to be provided to strive for the promotion of useful research activities.

4) Risk Theory, that IPR is a work containing risks. Intellectual Property Rights which is the result of a research contains risks which may allow other people to first disclose the method or improve it so that it is reasonable to provide legal protection for efforts or activities that carry risks.

5) Economic Growth Stimulus Theory, this theory recognizes that protection of IPR is a tool of economic development and what is meant by economic development is the overall objective of establishing an effective IPR protection system.

IPR is a source of material wealth for its owner, and one aspect of special IPR rights is economic rights. ${ }^{23}$ Economic rights are the rights to obtain economic benefits over intellectual property. The economic right is taken into account because IPR can be used / utilized by other parties in industry or trade that brings profits, in other words IPR is the object of trade. Muhammad also emphasized that in industrial and trade activities, economic benefits can not only be enjoyed by the owner but also by other parties. ${ }^{24} \mathrm{How}$ to obtain economic benefits, among others:

1) IPR is used to run a particular business for its own owner, for example trademarks and service marks.

2) Intellectual Property Rights is embodied in the form of an industrial design model and then marketed to consumers, for example architectural works.

3) Intellectual property rights are transferred to other parties through a license (permit) so that the owner gets a double profit from his own use and from licenses for example copyright is licensed to the producer, trademark rights are licensed to trading companies, patents are licensed to industrial companies.

In the context of SMEs, according to the Directorate General of Intellectual Property Rights of the Ministry of Law and Human Rights of the Republic of Indonesia (2004), it has been confirmed that IPR has a positive 
influence, at least there are several benefits that can be seen from the economic, legal protection and creativity side, including:

1) As a Company Asset, IPR is one of the key supporters so that the business can be successful because it can be used as a financial asset for the company. IPRs can be exploited by their owners through sales, licenses, transfers or can also be used as a means of capital planning. Even inventors / industrialists' patents because they promise no small profits, and can be used as a means to obtain / increase capital / profits.

2) As a Support for Business Development, a business that in producing certain products / services always strives to maintain that the quality of the products / services it produces is always good, guaranteed to immediately gain public trust. To attract the attention of the public and simultaneously introduce it quickly and tactically the use of certain brands is expected to realize that desire. IPR-based products that have been trusted by the community will be able to support further business development. Business development that can be done not only includes increasing the number of products / services produced but can also develop in the form of other products / services, or even with the increasing number of places of business.

3) As Legal Protection and Prevention of Unhealthy Business Competition and Enhancing Competitiveness, every business / business will not be separated from competition, both on a local, regional and international scale. With the availability of the IPR system it is expected that unhealthy competition can be prevented / eliminated. In practice, IPR protection systems are rarely used to prohibit competitors from producing the same / similar goods / services. Instead, through this system, efforts to limit competitors are made by offering the possibility to obtain a license. Through this mechanism, it is hoped that the distribution of products and related technologies to the licensee can be carried out. At the same time, commensurate royalty payments are expected to be obtained by IPR owners. Products, services and other works that empower the IPR system and have been trusted by the public will not only support further business development but can also increase competitiveness and gain more markets large.

4) As a Driver for Innovation and Creativity, IPR is an exclusive right imposed by the state as a tribute to one's intellectual work. Through this award, inventors / creators are expected to be encouraged / stimulated to innovate in further developing their intellectual work. 
5) As an Image Building, a quality product that is protected by IPR will be easily recognized and favored by the public. Furthermore, the use of IPR continuously will form an image of related products.

In the same context, in Central Java Province itself, the protection of economic rights is regulated through the Regional Regulation of the Province of Central Java Number 13 of 2013 concerning Empowerment of Micro, Small and Medium Enterprises, which in essence is empowering SMEs to:

1) realize the structure of the economy in a balanced, developing and just region;

2) grow, protect and develop SMEs to be tough and independent;

3) increasing the role of MSMEs in regional development, job creation, income distribution, poverty alleviation and economic growth;

4) increase public participation and the business world to grow SMEs;

5) increasing MSME productivity, competitiveness, and market share;

6) foster entrepreneurial spirit;

7) increase access to productive resources and wider markets;

8) enhance the role of MSMEs as strong, professional and independent economic actors; and

9) develop local superior products based on local resources.

In addition to the Regional Regulation, several other rules in Central Java that serve as guidelines in the protection, empowerment, and development of MSMEs are as follows:

1) Regional Regulation No. 2 of 2012 concerning Management Guidelines Cooperative.

2) Regional Regulation No. 13 of 2013 concerning Empowerment of Micro and Small and Medium Enterprises.

3) Governor Regulation No. 2 of 2012 concerning Technical Guidelines for Implementing Regional Regulation No. 2 of 2012 concerning Guidelines for Cooperative Management.

4) Instruction of the Governor of Central Java No. 518/23546 of 2011 concerning the Development of Superior Products in Rural Areas through the Cooperative-based One Village One Product (OVOP) Approach in Central Java Province.

5) Central Java Governor Circular No. 518/06544 on the 31st March 2011 concerning Strengthening Microfinance Institutions and Joint Business Groups by facilitating the Establishment Cooperative.

6) Central Java Governor Circular Letter No. No.518 / 15158 dated August 5, 2011 concerning Comprehensive Inactive Management of Cooperatives with Regencies / Cities 
7) Central Java Governor Circular No. 518/17567 dated 21 September 2011 concerning Central Java Souvenir and Food Shopping Centers in each Regency / City

8) Central Java Governor Circular No. 518/016736/2013 dated 25 September 2013 concerning the Development of Cooperatives as a Popular Economy Movement.

\section{Conclusion}

The implementation of the protection of economic rights for SMEs in Indonesia, especially in Central Java, is regulated in the Copyright Act, the SMEs Act, and several Regional Regulations in Central Java. These economic rights relate to the acquisition of copyrights and brands, as well as the economic benefits of SMEs products. The lack of copyright registration for SMEs must be encouraged by the government by making a special scheme that facilitates the copyright registration process. In a global context, these economic rights are also considered basic rights (including human rights) that must be fulfilled by the state by providing optimal and appropriate protection.

\section{E. Acknowledgments}

Authors would like to express the thakfullness to Faculty of Law, Universitas Negeri Semarang, as well as to Research and Community Services Unit Universitas Negeri Semarang.

\section{F. Declaration of Conflicting Interests}

The authors state that there is no potential conflict of interest in the research, authorship, and/or publication of this article.

\section{G. Funding}

Research and Community Services Universitas Negeri Semarang Grants

\section{H. References}

Alexander, G.S. (1985). 'Interpreting Legal Constructivism', Cornell Law Review, 7(1), 149-254.

Arifin, R., Waspiah, W., \& Latifiani, D. (2018). Penulisan Karya Ilmiah untuk Mahasiswa Hukum. Semarang: BPFH UNNES. 
Arliman, L. (2017). 'Perlindungan Hukum UMKM dari Eksploitasi Ekonomi dalam Rangka Peningkatan Kesejahteraan Masyarakat (UMKM Legal Protection from Economic Exploitation to Improve Social Welfare)'. Jurnal Rechtsvinding 6(3), 387-402.

Arto, A., dan Hutomo, B.S. (2013). "Enam Pilar Insektisida" Kebijakan Pengembangan dan Penguatan UMKM Berbasis Kerjasama Kemitraan dengan Pola CSR Sebagai Strategi Peningkatan Peran Pemerintah dan Perusahaan untuk Menjaga Eksistensi UMKM dalam MEA 2015’. Economics Development Analysis Journal 2(2): 98 109.

Cakrawibawa, R.A., \& Roisah, K. (2019). 'The Consumer Protection Issues Toward the Trademark Circulation of The Counterfeit Health Products', Law Reform, 15(2), 1-11.

Darwin, D. (2018). 'UMKM dalam Perspektif Pembiayaan Inklusif di Indonesia (MSMEs on Inclusive Financing Perspective on Indonesia)', Jurnal Ekonomi dan Pembangunan 26(1), 59-76.

Denzin, N., \& Lincoln, Y.S. (2000). "Introduction: The Discipline and Practice of Qualitative Research". In N Denzin and YS Lincoln, eds, Handbook of Qualitative Research, Second Edition. London: Sage.

Dewi, I.J. (2014). 'A Study on the Economic Contribution of Copyright and Related Right Industries in Indonesia'. Procedia - Social and Behavioral Sciences 115, 207-220.

Djulaeka, D. (2014). Konsep Perlindungan Hak Kekayaan Intelektual (Perspektif Kajian Filosofis HaKI Kolektif Komunal). Malang: Setara Press.

Ginting, E.R. (2012). Hukum Hak Cipta Indonesia. Bandung: PT. Citra Aditya Bakti.

Harvie, C. (2010). 'SMEs and Regional Production Networks', on Thanh, V.T., Narjoko, D., Oum, S. (eds). (2010). 'Integrating Small and Medium Enterprises (SMEs) into the More Integrated East Asia', ERIA Research Project Report No. 8.

Hayuningrum, Y.W., \& Roisah, K. (2015). 'Perlindungan Hak Ekonomi Terhadap Penggunaan Merek dalam Perjanjian Waralaba', Law Reform, 11(2), 255-263.

Hubeis, M. (2015). Prospek Usaha Kecil dalam Wadah Inkubator Bisnis. Bogor: Ghalia Indonesia.

Jaya, P.H.I. (2012). 'Trickle Down Effect: Strategi Alternatif dalam Pengembangan Masyarakat', WELFARE, Jurnal Ilmu Kesejahteraan Sosial, 1(1), 69-86.

Kusumanigtuti, S.S. (2009). Peranan Hukum dalam Penyelesaian Krisis Perbankan di Indonesia. Jakarta: Rajawali Press.

Muhammad, A.K. (2007). Kajian Ekonomi Hak Kekayaan Intelektual. Bandung: Citra Aditya Bakti.

Nuryadhyn, A. (2014). 'HKI Penting dalam Dunia Usaha', Online News, retrieved from https://bangka.tribunnews.com/2014/03/20/hkipenting-dalam-dunia-usaha. 
Roisah, K. (2015). 'Kebijakan Hukum "Tranferability" Terhadap Perlindungan Hak Kekayaan Intelektual di Indonesia', Law Reform, 11(2), 241-54.

Sicca, S.P. (2018). 'Kontribusi Koperasi ke PDB 2017 Capai 4,48 Persen, Setara Rp452 T', Online News, retrieved from https://tirto.id/kontribusi-koperasi-ke-pdb-2017-capai-448-persensetara-rp452-t-cCQc

Sihombing, E.N.A.M. (2018). 'Kebijakan Afirmatif Bagi Usaha Mikro, Kecil dan Menengah di Bidang Kekayaan Intelektual (Affirmative Policy for Micro, Small and Medium Enterprises in the Field of Intellectual Property)', Rechtsvinding, 7(3), 427-444.

Sukarmijana, S.S. dan Sapong, O.D.V. (2014). 'The Importance of Intellectual Property for SMEs: Challenges and Moving Forward'. UMK Procedia $1,74-81$.

Sukmadewi, Y.D. (2018). Kajian Legalitas dan Manajemen Merek Pada UMKM Munaku Sulam Pita Semarang', Law Reform, 14(2), 275-290.

Wilantara, R. F., \& Indrawan, R. (2016). Strategi dan Kebijakan Pengembangan UMKM: Upaya Meningkatkan Daya Saing UMKM Nasional di Era MEA. Bandung: Refika Aditama.

Salim, A. (2001). Teori dan Paradigma Penelitian Sosial (Pemikiran Norman K. Denzin dan Egon Guba, dan penerapannya). Yogyakarta: PT. Tiara Wacana.

Soelistyo, H. (2011). Hak Cipta Tanpa Hak Moral. Jakarta: Rajawali Press.

Sudaryanto, et.al. (2018). 'Strategi Pemberdayaan UMKM Menghadapi Pasar Bebas Asean', Online News Ministry of Finance, retrieved from https://www.kemenkeu.go.id/sites/default/files/strategi\%20pemberda yaan\%20umkm.pdf

Taufik, A.I. (2017). 'Evaluasi Regulasi dalam Menciptakan Kemudahan Berusaha Bagi UMKM', Rechtsvinding 6(3), 375-392.

Waspiah, W. (2019). Teori dan Perkembangan Hukum Kekayaan Intelektual (Dinamika Nasional dan Internasional). Semarang: BPFH UNNES.

Wiradirja, I.R., \& Munzil, F. (2018). Pengetahuan Tradisional dan Hak Kekayaan Intelektual (Perlindungan Pengetahuan Tradisional Berdasarkan Asas Keadilan Sui Generis Intellectual Property System). Bandung: Refika Aditama.

Yoserwan. (2006). Hukum Ekonomi Indonesia dalam Era Reformasi dan Globalisasi. Padang: Andalas University Press.

\section{LAWS \& REGULATIONS}

Constitution of Indonesia 1945

Law Number 20 of 2008 concerning Micro, Small and Medium Enterprises

Regional Regulation No. 2 of 2012 concerning Management Guidelines Cooperative.

Regional Regulation No. 13 of 2013 concerning Empowerment of Micro and Small and Medium Enterprises. 
Governor Regulation No. 2 of 2012 concerning Technical Guidelines for Implementing Regional Regulation No. 2 of 2012 concerning Guidelines for Cooperative Management.

Instruction of the Governor of Central Java No. 518/23546 of 2011 concerning the Development of Superior Products in Rural Areas through the Cooperative-based One Village One Product (OVOP) Approach in Central Java Province.

Central Java Governor Circular No. 518/06544 on the 31st March 2011 concerning Strengthening Microfinance Institutions and Joint Business Groups by facilitating the Establishment Cooperative.

Central Java Governor Circular Letter No. No.518 / 15158 dated August 5, 2011 concerning Comprehensive Inactive Management of Cooperatives with Regencies / Cities

Central Java Governor Circular No. 518/17567 dated 21 September 2011 concerning Central Java Souvenir and Food Shopping Centers in each Regency / City

Central Java Governor Circular No. 518/016736/2013 dated 25 September 2013 concerning the Development of Cooperatives as a Popular Economy Movement.

Copyrights (C) 2020 by Auhtor(s). This work is licensed under a Creative Commons Attribution-NonCommercial-ShareAlike 4.0 International License. All writings published in this journal are personal views of the authors and do not represent the views of this journal and the author's affiliated institutions. 